Volume 50 - Issue 1 • March 2014 • ISSN: 0022-2267

\title{
Journal of Linguistics $\int$
}

song of the unknown grapheme

sang of the unkent lichen

context is all quoth the linguist the crack is wall spored a lichen down to a native speaker who wept fax to a fungal partner who shone punctuation is but said lichen of bacteria as but the rift crust is your discontents made ruly matter mossy free living not algal bloom can there but be words enough for how little or no is to type still the imperial litter oh data fruit the oldest living given thing bit virgule fleuron come manicule how crustose foliose and fruticose oh hashtags curl up in bullet points beard moss unfurl a broken cortex and this stark fungi of asterisms and deictic vegetative propagules yes punctuation is such lichen of yes lichen is such punctuation of your dissertated content drifting even a pre-cambrian morph to gold into sentence laws of the thallus into a colonising as conjunctions imposing clouds of graphematicity made nitrogeneous waste to gerund in inscription of an anthropology in prescriptions of an industrial as befits no colon worth its semi revolution calling for apostrophe lozenge now no obelus nor pilcrow o anaphora no arthonia galactites yes capitals do brand our science yes heavy metals do kill our kind embracing too the comma as a love polluting to lost veneers on aged and to put too fine a point on it buildings as to punctuate the air there is no linguistics worth its there is no lichen scale but maps cognate that doesn't fall in with in pulls of sulphur dioxide a new punctuation and in so falling who poverty and so many cryptic moths hears the I sing that accompanies there past hydrogen flouride sing all our silent misrepresentations down wind of the unsung prolepsis and passes such as silence dashed who' could survive the nuclear war 


\title{
JOURNAL OF LINGUISTICS
}

THE JOURNAL OF THE LINGUISTICS ASSOCIATION OF GREAT BRITAIN

Professor Nigel Fabb
University of Strathclyde

ED I TORS

\author{
Professor Robert D. Borsley \\ University of Essex \\ REVIEW EDITOR \\ Dr Peter Ackema \\ University of Edinburgh
}

EDITORIAL BOARD

\author{
David Adger Queen Mary, London \\ Adam Albright $M I T$ \\ James P. Blevins Cambridge \\ Jonathan D. Bobaljik Connecticut \\ Ning Chunyan Tianjin Normal \\ University, China \\ Janet Dean Fodor $C U N Y$ \\ Eric Haeberli Geneva \\ Laurence R. Horn Yale \\ Bill Idsardi Maryland \\ D. Robert Ladd Edinburgh
}

Louise McNally Pompeu Fabra

Ad Neeleman $U C L$

Colin Phillips Maryland

Gillian Ramchand Tromsø

Malka Rappaport Hovav Hebrew

University of Ferusalem

Junko Shimoyama $\mathrm{Mc}$ Gill

Andrew Simpson Southern California

Andrew Spencer Essex

Sali Tagliamonte Toronto

Adam Ussishkin Arizona

MANAGING EDITOR: Ewa Jaworska

Subscriptions Fournal of Linguistics (ISSN $0022-2267$; electronic ISSN I469-7742) is published three times a year in March, July and November. Three parts form a volume. The subscription price of volume 50 (2014) is $£ 224$ (US\$379 in the USA, Canada and Mexico) for institutions print and electronic, institutions electronic only $£_{1}$ I5 $/ \$ 30$ I; $£ 76$ (US\$ I 29) for individuals ordering direct from the publisher and certifying that the journal is for their personal use. Single parts are $£ 76$ (US\$ I 29 in the USA, Canada and Mexico). EU subscribers (outside the UK) who are not registered for VAT should add VAT at their country's rate. VAT registered subscribers should provide their VAT registration number. Members of the Linguistics Association of Great Britain may purchase the journal at a special rate via the Association.

Orders, which must be accompanied by payment, may be sent to a bookseller, subscription agent or direct to the publisher: Cambridge University Press, The Edinburgh Building, Shaftesbury Road, Cambridge CB2 8RU, UK; or in the USA, Canada and Mexico: Cambridge University Press, Journals Fulfillment Department, Ioo Brook Hill Drive, West Nyack, New York ro994-2133.

Japanese prices for institutions are available from Kinokuniya Company Ltd, P.O. Box 55, Chitose, Tokyo i 56, Japan. Prices include delivery by air.

Copying This journal is registered with the Copyright Clearance Center, 222 Rosewood Drive, Danvers, MA or 923, USA. Organizations in the USA who are also registered with the C.C.C. may therefore copy material (beyond the limits permitted by sections Io7 and 108 of the US Copyright law) subject to payment to C.C.C. of the per-copy fee of $\$$ I 2.00. This consent does not extend to multiple copying for promotional or commercial purposes. Code 0022-2267/2008.

ISI Tear Sheet Service, 35 o I Market Street, Philadelphia, PA I 9 I 04, USA, is authorized to supply single copies of separate articles for private use only.

Organizations authorized by the Copyright Licensing Agency may also copy material subject to the usual conditions.

For all other use, permission should be sought from Cambridge or the American Branch of Cambridge University Press.

Notes for Contributors are printed on the inside back cover and are available in full via journals.cambridge.org/lin.

Information on Fournal of Linguistics and all other Cambridge journals can be accessed via journals.cambridge.org/lin and in North America via http://www.cup.org/.

This journal issue has been printed on FSC-certified paper and cover board. FSC is an independent, non-governmental, not-for-profit organization established to promote the responsible management of the world's forests. Please see www.fsc.org for information.

(C) Cambridge University Press 20I4

Printed in the UK by Bell and Bain Ltd

For the three covers of our fiftieth anniversary volume, the Fournal has commissioned three new poems on the topic of language. For this first issue, the two texts on the cover are poems by Drew Milne entitled 'song of the unknown grapheme' along with a translation of this poem, 'sang of the unkent lichen', presented in an image text collage conceived by Drew Milne, using a photograph by Sarah Hayden. 